\title{
METODOLOGI PENILAIAN KUALITAS HUNIAN PASKA BENCANA SEBAGAI EVALUASI STRATEGI REKONSTRUKSI: ANALISIS FAKTUAL DAN PERSEPTUAL
}

\author{
Maria Ariadne Dewi Wulansari \\ Departemen Arsitektur dan Perencanaan, Fakultas Teknik, Universitas Gadjah Mada. \\ maria.ariadne.d@ugm.ac.id \\ Dimas Wihardyanto \\ Departemen Arsitektur dan Perencanaan, Fakultas Teknik, Universitas Gadjah Mada. \\ dimas@ugm.ac.id
}

\begin{abstract}
Abstrak
Salah satu target utama dalam rekonstruksi paska bencana ialah tersedianya hunian bagi korban bencana yang kehilangan tempat tinggalnya. Dalam pengadaan hunian paska bencana terdapat berbagai macam strategi rekonstruksi. Pada penelitian ini dibahas mengenai kemungkinan menggunakan penilaian kualitas hunian sebagai alat untuk melakukan evaluasi terhadap strategi rekonstruksi. Metode penilaian kualitas hunian baik secara faktual maupun perseptual dipaparkan sebagai pengantar, kemudian disajikan perbandingan dari beberapa penelitian terdahulu mengenai kualitas hunian paska bencana. Dari penelitian ini, disimpulkan bahwa penilaian kualitas hunian paska bencana merupakan cara yang efektif untuk melakukan evaluasi terhadap strategi rekonstruksi. Penilaian kualitas hunian paska bencana itu sendiri dapat menggunakan pendekatan faktual, perseptional, maupun perpaduan keduanya, sesuai dengan obyek pengamatan yang dipilih.
\end{abstract}

Kata-kata Kunci: kualitas hunian, paska bencana, analisis faktual, analisis perseptual

\section{SCORING METHOD OF THE QUALITY OF POST DISASTER HOUSING AS RECONSTRUCTION STRATEGY'S EVALUATION : FACTUAL AND PERCEPTUAL ANALYSIS APPROACH}

\begin{abstract}
One of post disaster recontruction's main targets is providing proper housing for the victims who lost their homes. In post-disaster housing procurement there are various reconstruction strategies. This research discusses about ability to rate the quality of housing in evaluating the reconstruction strategy. Scoring method of the quality of housing, factually or perceptually, both are explained as preface. And then comparation of previous study about the quality of post disaster housing is discussed. From this research it learned that scoring of the quality of post disaster housing is an effective way to evaluate the reconstruction strategy. The scoring method of the quality of post disaster housing itself, can be seen from different approaches, the factual analysis approach, the perceptual analysis approach, or both, depends on the chosen study object.
\end{abstract}

Keywords: quality of housing, post disaster, factual analysis, perceptual analysis 


\section{Pendahuluan}

Bencana alam yang melanda kehidupan manusia tidak hanya menelan korban jiwa, tetapi juga menyebabkan kerusakan dan kehancuran pada aspek fisik, termasuk bangunan hunian masyarakat. Maka dalam penanganan paska bencana, hunian menjadi salah satu kebutuhan yang harus segera dipenuhi.

Dalam menanggapi bencana, penyediaan hunian paska bencana menjadi dasar yang baik dalam rangkaian proses recovery paska bencana, mengingat hunian/papan merupakan salah satu kebutuhan primer manusia yang harus dipenuhi untuk kelangsungan hidupnya. Disampaikan oleh Batchelor (2011) bahwa keberadaan hunian paska bencana mempengaruhi semua aspek rumah tangga dan pemulihan masyarakat. Adanya dukungan dalam bentuk hunian yang memadai, yang diikuti dengan kelengkapan penyediaan pelayanan dasar, dapat menjamin keamanan masyarakat serta mengkatalisis peluang mata pencaharian dan pemulihan ekonomi.

Dalam proses penyediaan hunian paska bencana, ada beberapa pendekatan strategi yang dapat dilakukan. Pada umumnya, mengingat kepentingan untuk tidak hanya menyediakan sarana perumahan tetapi juga membangkitkan kembali kehidupan masyarakat korban bencana, pendekatan strategi pengadaan hunian melibatkan partisipasi masyarakat. Adanya partisipasi keluarga yang terkena dampak bencana dalam proses perencanaan, desain, dan konstruksi dari program penampungan dapat mengembangkan keterampilan dan jaringan sosial, yang dapat memungkinkan keluarga untuk mengatasi trauma dengan lebih baik, mendukung pemulihan sosial, serta pembentukan kembali struktur pemerintahan dan aturan hukum. Sebuah solusi teknis yang sesuai mengenai tempat tinggal paska bencana, dikombinasikan dengan proses partisipatif dalam membangkitkan kesadaran masyarakat paska bencana dapat berkontribusi dalam jangka panjang untuk pengurangan risiko bencana dan menciptakan masyarakat yang lebih aman.

Mengingat intensitas bencana di dunia yang sangat tinggi dan tidak terduga, perlu adanya evaluasi terhadap strategi pengadaan hunian paska bencana, sehingga dapat memberi masukan untuk optimasi pada penanganan bencana selanjutnya.

\section{Studi Evaluasi Strategi Rekonstruksi Bencana}

Dari studi literatur yang dilakukan, strategi pengadaan rumah paska bencana dapat dievaluasi melalui:

1. Ketercapaian Target

Target dalam rekonstruksi terbagi menjadi dua aspek, yaitu aspek target fisik dan target non fisik. Salah satu ketercapaian target fisik yang dimaksud ialah ketepatan penyelesaian program rekonstruksi sesuai dengan timeline rekonstruksi yang ditetapkan. Hunian yang dibangun dalam rekonstruksi merupakan pondasi dari perbaikan taraf kehidupan korban bencana, maka target pengadaan hunian haruslah dilakukan dengan tepat waktu. Selain aspek ketepatan waktu, juga harus diperhatikan ketercapaian jumlah sesuai dengan yang ditargetkan. Pada aspek non fisik, pemahaman masyarakat akan prinsip bangunan tahan bencana juga harus tercapai, terlebih pada daerah yang mengalami bencana secara siklik. Siklus bencana yang mungkin kembali datang ini juga menuntut adanya pencapaian terhadap kesadaran akan kebutuhan untuk evakuasi darurat sewaktu-waktu. Dalam konteks pembangunan kembali maupun relokasi, warga juga harus memiliki pemahaman terhadap konsep sustainable settlement and community sehingga dapat mencapai taraf kehidupan yang lebih baik lagi (Leon et al, 2009).

2. Keberhasilan Penggunaan

Keberhasilan penggunaan lingkungan binaan hasil rekonstruksi dapat dinilai dari beberapa aspek. Secara mudahnya dapat dilihat dari persentase penghunian, berapa persen dari hunian yang disediakan yang digunakan oleh warga. Pada banyak kasus, ditemukan tingkat penghunian yang rendah pada awal-awal masa rekonstruksi karena ketidaksesuaian hunian paska bencana dengan faktor sosio kultural masyarakat (Dola dan Parva, 2012). Selain itu, 
keberhasilan ini juga dilihat dari kecukupan ketersediaan ruang dalam hunian dan kemudahan akses menuju maupun dari hunian paska bencana.

3. Kualitas Fisik Bangunan

Kualitas fisik bangunan paska bencana juga merupakan salah satu indikator dalam penilaian evaluasi strategi rekonstruksi (Ratnayake dan Rameezdeen, 2008). Untuk meminimalisir kerusakan jika terjadi bencana lagi, maka bangunan harus memiliki ketahanan terhadap bencana, sesuai dengan resiko bencana pada daerah tersebut. Setelah memenuhi syarat ketahanan, bangunan juga harus dapat memenuhi kebutuhan dalam aspek fungsional, kelengkapan ruang yang ada dalam memenuhi kebutuhan aktivitas penggunanya. Untuk itu, juga diperhatikan kelengkapan dan kondisi fasilitas pendukung dalam hunian paska bencana. Dalam konteks hunian tetap, juga diperlukan perhatian terhadap aspek estetika bangunan, terutama kaitannya dengan arsitektur vernakular setempat (Al-Hussaini et al, 1999). Penilaian terhadap kualitas fisik juga bisa dilakukan pada fase setelah dilakukan pengembangan hunian oleh pemilik bangunan. Contohnya, seperti yang dilakukan oleh Rini (2012) yang mengevaluasi keberhasilan strategi rekonstruksi dari penilaian ketahanan bencana hunian setelah dikembangkan oleh pemilik bangunan.

4. Kualitas Sosial Masyarakat

Seperti telah disebutkan sebelumnya, hunian paska bencana akan berperan sebagai pondasi dalam recovery masyarakat. Maka evaluasi terhadap strategi yang diambil dapat dilihat dari kualitas sosial masyarakat hasil rekonstruksi (Samaddar dan Okada, 2006). Langkah paling awal ialah memastikan setiap unit yang diterima oleh masyarakat berada dalam kondisi yang sama satu sama lain. Setelah itu dapat dilakukan penilaian terhadap penerimaan masyarakat terhadap tata permukiman maupun tata ruang dalam hunian (Önder et al, 2010). Hal ini biasanya berkaitan dengan tradisi bermasyarakat yang dimiliki pengguna. Dalam konteks relokasi, maka perlu dilihat adanya hubungan antara warga relokasi dengan warga asli di sekitar pemukiman mereka. Selain itu, pada hunian yang telah dihuni selama 1-2 tahun, sudah bisa dilakukan penilaian terhadap keberhasilan hunian paska bencana dalam mendukung recovery warga (Kamel dan Loukaitou-Sideris, 2003).

5. Keberlanjutan Hunian

Hunian paska bencana haruslah memungkinkan adanya keberlanjutan, karena berkaitan dengan keberlangsungan hidup penghuninya. Untuk memperbaiki kinerja bangunan paska bencana, salah satu pendekatan yang digunakan adalah penerapan sifat upgradable pada bangunan. Maksud dari sifat upgradable ini ialah pada proses penghunian bangunan, hunian paska bencana dapat ditingkatkan dari waktu ke waktu untuk menjadi tempat tinggal permanen yang diinginkan penghuninya. Hal ini dicapai melalui pemeliharaan, pengembangan, atau dengan mengganti bahan asli dengan bahan alternatif yang lebih tahan lama (Collins, et al. 2010). Selain itu, juga dapat dilakukan penilaian terhadap keberlanjutan pemukiman dan komunitas, dalam artian keberhasilan dalam menghidupkan kembali budaya hidup bermasyarakat seperti pada kondisi semula.

Dari pemaparan di atas, maka secara lebih spesifik dapat disimpulkan bahwa penilaian kualitas hunian paska bencana merupakan salah satu cara untuk melakukan evaluasi terhadap strategi rekonstruksi yang telah diterapkan pada suatu kawasan bencana. Dalam metodologi penilaian kualitas hunian paska bencana itu sendiri, dapat dilihat dari dua pendekatan berbeda, yaitu pendekatan faktual maupun perseptional.

\section{Metodologi Penelitian Penilaian Kualitas Hunian Metode Analisis Faktual}

Pada metode ini, penilaian terhadap kualitas hunian didasarkan pada ketercapaian standarstandar yang sudah ditentukan sebelumnya. Standar-standar ini dapat berupa besaran unit hunian 
yang didasarkan parameter tertentu, seperti yang tertulis dalam data arsitek ataupun Time Saver's Standard. Dapat juga berupa ketetapan yang ditentukan pemerintah atau dinas-dinas terkait, seperti pedoman teknis bangunan dan sebagainya, maupun aturan tata bangunan, tata kawasan, serta infrastruktur yang dikeluarkan oleh pemerintah setempat. Standar-standar tersebut menjadi syarat minimal yang harus dipenuhi dalam tata bangunan maupun kawasan. Baik tidaknya kualitas suatu lingkungan binaan dilihat dari ketercapaian standar-standar tersebut, dengan melihat selisih antara kondisi lingkungan binaan dengan standar yang ditentukan.

\section{Metode Analisis Perseptual}

Pada metode ini, penilaian kualitas hunian didasarkan pada persepsi dari masing-masing pengguna. Persepsi bersifat sangat subjektif, karena berkaitan terhadap cara pandang individu terhadap suatu keadaan. Dalam persepsi, terjadi proses dimana seorang memilih, mengolah, dan mengambil intepretasi dari stimulan yang diterima.

Terhadap stimulan atau kondisi yang diterima, tiap individu dapat memilih sudut pandangnya masing-masing. Individu dapat memilih untuk lebih melihat sisi positif yang menimbulkan simpati dari kondisi tersebut, melihat pada sisi dari stimulan yang memenuhi kebutuhannya, menyisir aspekaspek dari stimulan yang dirasa mengganggu/tidak sesuai, atau langsung memilih untuk menyingkirkan aspek dari stimulan yang dirasa paling tidak disukai/mengganggu.

Dalam mengolah stimulan yang diterima, individu dapat mengelompokkan sesuai keinginannya masing-masing. Stimulan dapat diterima sebagai obyek yang dirasa paling menonjol dan yang hanya merupakan latar belakang, sebagai satu kesatuan impresi atau kesatuan konsep utuh, maupun menyusun atau melengkapi stimulan yang ada menjadi suatu kesatuan utuh.

Setelah itu individu akan mengambil interpretasi dari stimulan yang diterima. Interpretasi yang diambil dapat berasal dari penampilan fisik dari stimulan yang diterima, pemaknaan universal yang melekat pada stimulan, kesan awal yang dirasakan dari stimulan, menarik kesimpulan langsung tanpa melihat keseluruhan kondisi stimulan, atau bergantung pada gambaran populer yang melekat pada stimulan.

\section{Obyek dan Metode Penelitian Penilaian Kualitas Hunian Paska Bencana}

Dalam penelitian terdahulu mengenai kualitas hunian secara umum, maupun kualitas hunian paska bencana pada khususnya, banyak obyek penelitian yang dipilih oleh masing-masing peneliti, antara lain dapat berupa:

a. Struktur hunian

Penilaian kualitas struktur hunian biasa dilakukan dengan metode analisis faktual, yakni dengan menguji kekuatan bangunan dengan bertumpu pada syarat minimum kekuatan struktur bangunan terhadap variabel-variabel yang diujikan, seperti nilai kuat tekan, kuat tarik, dan sebagainya. Namun aspek struktur hunian juga bisa dinilai dengan metode perseptual, misalnya melalui pengamatan terhadap persepsi pengguna terhadap tingkat kerusakan struktur bangunan (Saleh, 2010), persepsi kepuasan pengguna terhadap kelengkapan utilitas bangunan dan ketahanan struktur bangunan (Kwanda, dkk., 2001), atau seperti yang dilakukan oleh Pamungkas dan Harianto (2012) yang menggunakan pendekatan kepuasan perseptual pengguna terhadap ketahanan elemen bangunan terhadap gangguan rayap dan gangguan iklim, serta kondisi fisik elemen-elemen bangunan.

b. Desain

Penilaian kualitas desain secara faktual dilakukan dengan melihat ketercapaian standar-standar ukuran yang sudah ditentukan, seperti lebar tangga, lebar selasar, ukuran ruangan dibandingkan dengan jumlah kapasitas pengguna, dan sebagainya. Kualitas desain juga dapat dilihat dari aspek estetika atau penampilan, yaitu dengan menilai tampilan dari lingkungan binaan berdasarkan norma-norma estetika yang ada, baik dari segi komposisi hingga 
harmonisasi warna yang digunakan secara teoritis. Secara perseptual, kualitas desain hunian dapat dilihat dari persepsi pengguna terhadap luasan atau ukuran ruang (Saleh, 2010; Pamungkas dan Harianto, 2012), ketersediaan ruang-ruang dalam hunian (Saleh, 2010), susunan/tata letak ruangan (Kwanda, dkk., 2001; Pamungkas dan Harianto, 2012), maupun orientasi bangunan (Kwanda, dkk., 2001).

c. Kenyamanan fisik

Penilaian kualitas kenyamanan fisik secara faktual dilakukan dengan menilai kenyamanan thermal, visual, serta audial dalam lingkungan binaan. Penilaian ini dilakukan dengan melakukan pengukuran/pengujian pada lingkungan binaan, kemudian hasil pengukuran tersebut dibandingkan dengan parameter yang sudah ditentukan sebagai nilai yang harus dipenuhi. Secara perseptual, kenyamanan fisik hunian dapat dilihat melalui pengamatan terhadap persepsi pengguna terhadap luasan bukaan hunian dalam kaitannya dengan ketersediaan udara segar dan cahaya alami (Saleh, 2010; Pamungkas dan Harianto, 2012).

d. Fungsional

Penilaian kualitas fungsional dilakukan dengan menilai kelayakan lingkungan binaan dalam mewadahi fungsi di dalamnya. Penilaian ini dapat dilakukan dengan melihat kelengkapan elemen dalam lingkungan binaan yang harus terpenuhi untuk mendukung kegiatan/aktivitas yang diwadahinya. Pada aspek ini, kelengkapan fasilitas pendukung kegiatan pengguna dan keterjangkauan fasilitas umum termasuk di dalamnya. Selain pemenuhan kelengkapan, dapat juga dilihat persepsi pengguna terhadap sarana dan prasarana yang ada, misalnya persepsi mengenai kualitas dan ketersediaan jalan, air bersih, saluran limbah dan air hujan, serta listrik, kualitas dan ketersediaan sarana penunjang aktivitas seperti sarana pendidikan, kesehatan, peribadahan, perbelanjaan, olahraga, dan taman (Kwanda, dkk., 2001; Saleh, 2010; Pamungkas dan Harianto, 2012).

e. Keterlibatan Masyarakat dalam Pengadaan Hunian Paska Bencana

Leon, dkk. (2009) menyatakan bahwa kualitas hunian paska bencana berkaitan dengan, adanya proses partisipatif dan konsultatif dalam pengadaannya. Hal ini didukung oleh Samaddar dan Okada (1999) yang menyatakan bahwa adanya partisipasi masyarakat dalam tiap tahapan rekonstruksi akan meningkatkan kualitas hunian paska bencana yang dihasilkan. Secara lebih spesifik, Rini (2012) menyatakan bahwa adanya proses pembelajaran adaptif dalam proses pengadaan hunian paska bencana akan meningkatkan penerapan ketahanan bencana pada hunian yang dihasilkan.

Dengan menilai aspek-aspek di atas, dapat diperoleh data kualitas hunian paska bencana. Data kualitas hunian paska bencana ini dapat dijadikan sarana untuk melakukan penilaian terhadap strategi rekonstruksi yang telah diterapkan pada proses pengadaan hunian paska bencana tersebut. Evaluasi ini akan sangat bermanfaat untuk pengambilan keputusan rekonstruksi paska bencana di waktu yang akan datang.

\section{Kesimpulan}

Dari pemaparan di atas, maka dapat disimpulkan bahwa penilaian kualitas hunian paska bencana merupakan salah satu cara yang efektif untuk melakukan evaluasi terhadap strategi rekonstruksi yang telah diterapkan pada suatu kawasan bencana. Penilaian kualitas hunian paska bencana itu sendiri, dapat dilihat dari pendekatan faktual maupun perseptional, bahkan dapat juga dilihat dari dua sisi sekaligus. Obyek dalam penelitian kualitas hunian paska bencana dapat dilihat dari aspek struktur hunian, aspek desain hunian, aspek kenyamanan fisik, aspek fungsional, maupun keterlibatan masyarakat dalam proses pengadaan hunian tersebut. Masing-masing aspek tersebut dapat dinilai melalui pendekatan faktual maupun perseptional. 


\section{Daftar Pustaka}

Al-Hussaini, T. M., Seraj, S. M., Islam, M. K., Safiullah, A. M. M., Choudhury, J. R. (1999). A Methodology For Selection Of Post Disaster Shelter. H\&H Dhaka99

Batchelor, Victoria. (2011). Tarpaulins, transitional shelter or permanent houses : how does the shelter assistance provide affect the recovery of communities after disaster? Dissertation on Oxford Brookes University

Collins, Sam. Corsellis, Tom. Vitale, Antonella. (2010).Transitional Shelter: Understanding Shelter from The Emergency Through Reconstruction and Beyond. ALNAP. Diakses melalui www.sheltercenter.org

Dola, K. and Parva, M. (2012). Transformation Of Earthquake Disaster Victims' Shelter Into Sustainable Home: The Case Of Lar City, Iran. ALAM CIPTA, International Journal of Sustainable Tropical Design Research and Practice. Universiti Putra Malaysia. Volume 5 (2) December 2012

Kamel, Nabil M. O. and Loukaitou-Sideris, Anastasia (2003). Residential Assistance and Recovery Following the Northridge Earthquake. Urban Studies, Vol. 41, No. 3, 533-562, March 2004.

Kwanda, T., Rahardjo, J., Wardhani, M.K. (2001). Analisis Kepuasan Penghuni Perumahan Sederhana di Denpasar Berdasarkan Faktor Lokasi, Prasarana, Sarana, Kualitas Bangunan, Desain dan Harga. Dimensi Teknik Arsitektur Vol. 29, No. 2, Desember 2001: 117 - 125.
Leon, E., Kelman, I., Kennedy, J., and Ashmore,J. (2009). Capacity Building Lessons From A Decade Of Transitional Settlement And Shelter. International Journal Of Strategic Property Management (2009) 13, 247-265

Önder, D. E., Köseoğlu, E., Bġlen, Ö. (2010). The Effect Of User Participation In Satisfaction: Beyciler After-Earthquake Houses In Düzce. Itu $\mathrm{A} \mid \mathrm{Z}$

Pamungkas, H.B.E, Harianto, F. (2012). Analisis Kualitas Perumahan Mutiara Regency Sidoarjo. Jurnal IPTEK Vol 16 No.1 Mei 2012

Ratnayake R.M.G.D., Rameezdeen, Raufdeen. (2008).Post Disaster Housing Reconstruction: Comparative Study Of Donor Driven Vs. Owner Driven Approach. International Conference on Building Education and Research (BEAR)

Rini, Johanita Anggia. (2012). Evaluasi Penerapan Prinsip Tahan Gempa pada Renovasi atau Rekonstruksi Rumah Pasca Gempa 2006 di Yogyakarta. Tesis Magister, Institut Teknologi Bandung.

Saleh, Sakhrul Dachlan. (2010). Kajian Kualitas Bangunan Rumah Pondokan Terhadap Kenyamanan Huni Berdasarkan Persepsi Penghuni di Permukiman Sekitar Kampus Universitas Hasanuddin. Masters Thesis, Universitas Diponegoro.

Samaddar, S., Okada, N. (2006). Participatory Approach for Post-Earthquake Reconstruction in the Villages of Kachchh, India. Annuals of Disas. Prev. Res. Inst., Kyoto Univ., No. 49 B, 2006 